DOI: $\underline{10.32702 / 2307-2105-2021.11 .93}$

УДК 658.84

\author{
A. Dzyubina
}

$P h D$ in Economics, Associate Professor,

Associate Professor of the Department of Management of Organizations, Institute of Economics and Management, Lviv Polytechnic National University, ORCID ID: 0000-0002-2971-5830

K. Yanko

Student, Institute of Economics and Management,

Lviv Polytechnic National University

ORCID ID: 0000-0002-4401-221X

\title{
THE ROLE OF E-COMMERCE IN OVERCOMING BUSINESS CRISIS IN A COVID-19 PANDEMIC
}

\author{
A.В. Дзюбіна, \\ к. е. н., доцент, доцент кафедри менеджменту організацій, Інститут економіки $і$ \\ менеджменту, Національний університет «Львівська політехніка» \\ К. В. Янко, \\ студентка, Інститут економіки і менеджменту, \\ Національний університет «Львівська політехніка»
}

\section{РОЛЬ ЕЛЕКТРОННОЇ КОМЕРЦІЇ У ПОДОЛАННІ КРИЗОВИХ ЯВИЩ БІЗНЕСУ В УМОВАХ ПАНДЕМІЇ СОVID-19}

The article considers the peculiarities of doing business in a COVID-19 pandemic. It has been found that e-commerce is an effective tool in overcoming the crisis for businesses in such conditions. The experience of modern world companies in the electronic market is analyzed in detail. The basic tools of doing business in a COVID-19 pandemic have been found to be ineffective. Therefore, the need to find the latest ways to overcome the crisis of business is justified. It has been found that the online sale of goods and services in the context of the COVID-19 pandemic is one of the most effective ways to increase profitability for modern business. Ways to intensify the activities of modern companies in electronic markets are proposed. The directions of state support of business in the field of e-commerce are specified.

In this article authors described business model transformation of such types of business that were the most vulnerable: restaurant business, beauty salons, cinemas and theatres. The formation of a new business model was based on examples of real business experience from different countries. The expediency of using the leading online platforms for broadcasting movies and theater performances is substantiated. Recommendations for modern companies to improve pricing policy in the context of the COVID-19 pandemic are made. The process of transformation of business models in such circumstances is described as a marketing complex (4P). Particular attention is paid to the recommendations for the formation of certain elements of the marketing complex in the restaurant business, beauty salons, theaters and cinemas in a COVID-19 pandemic.

The processes of digitalization of services to citizens by the state are studied. The role of digitalization in improving and facilitating the provision of key services by citizens has been clarified. 
The potential of implementation of the concept of e-commerce in modern business in the conditions of COVID-19 pandemic is investigated. The positive impact of increasing access to electronic markets of modern companies in terms of GDP has been clarified. The expediency of paying special attention to cybersecurity during online transactions is considered.

У статті розглянуто особливості ведення бізнесу в умовах пандемї COVID-19. 3'ясовано, щзо електронна комериія є дієвим інструментом у подоланні кризових явищ для підприємств за таких умов. Детально проаналізовано досвід роботи сучасних світових компаній на електронному ринку. 3'ясовано, що базові інструменти ведення бізнесу в умовах пандемії COVID-19 виявилися неефективними. Тому обтрунтовано необхідність пошуку новітніх напрямів подолання кризових явищ бізнесу. 3'ясовано, щуо онлайн-продаж товарів та послуг в умовах пандемії COVID-19 є одним з найдієвіших напрямів зростання прибутковості для сучасного бізнесу. Запропоновано шляхи активізування діяльності сучасних компаній на електронних ринках. Конкретизовано напрями державної підтримки бізнесу у сфері електронної комериії.

Описано особливості трансформації бізнес-моделей таких видів бізнесу, які були одними з найбільш вразливих в умовах пандемії COVID-19: ресторанний бізнес, салони краси, кінотеатри та театри. Формування нової бізнес-моделі базувалося на прикладах реального підприємницького досвіду з різних країн. Обтрунтовано дочільність використання провідних онлайн-платформ для транслювання кінофільмів та театральних вистав. Подано рекомендачії для сучасних компаній щодо удосконалення цінової політики в умовах пандемії COVID-19. Прочес трансформачії бізнес-моделей за таких обставин описано у вигляді комплексу маркетингу (4P). Особливу увагу приділено рекомендаціям щуодо формування окремих елементів комплексу маркетингу в ресторанному бізнесі, салонах краси, театрах та кінотеатрах в умовах пандемії COVID-19.

Досліджено прочеси діджиталізації послуг громадянам з боку держави. 3'ясовано роль діджиталізащії у покращенні та спрощенні отримання ключових послуг громадянами.

Досліджено потенціал імплементації конщепиії електронної комериії у сучасний бізнес в умовах пандемії COVID-19. 3'ясовано позитивний вплив активізування виходу на електронні ринки сучасних компаній у наромуванні ВВП. Розглянуто доиільність приділення особливої уваги кібербезпеці під час здійснення онлайн-трансакцій.

Keywords: e-commerce; e-business; business model; digitalization; marketing mix; COVID-19; pandemic.

Ключові слова: електронна комериія; електронний бізнес; бізнес-модель; діджиталізація; маркетинговий комплекс; COVID-19; пандемія.

Problem statement. Pandemic of COVID-19 has interfered business in Ukraine and around the world a lot. However, for many companies transformation of business to the e-commerce has given them an opportunity to keep going.

Analysis of recent research and publications. Ukrainian scientists such as Olha Yatsenko, Anastasiia Hriazina, Oksana Shevchyk [17], Kapranova Larysa, Kapranov Maksym [11], Daria Panfilova [20], Olexandr Yudin, Mariana Makarova, Ruslan Lavreniuk [32] and others have been writing about e-commerce and digitalization in their articles. In the research of these scientists the general principles of e-business were considered. However, the special conditions of the COVID-19 pandemic require fundamentally new approaches to e-commerce.

Formulation of the objectives of the article. The aim of the article is to make an introduction to e-commerce with examples and to show how such business model can be implemented while pandemic.

Presentation of the main research material. Today a lot of companies are using e-commerce as a business model and one of the reason is current dangerous situation that has appeared because of pandemic. E-commerce it is the phenomenon which has appeared in 1960th and couldn't exist without the internet. Simply put e-commerce is the commerce done via internet. From the very beginning it was used among transport companies in US. However, today it is a very popular type of doing business and in future it might replace the traditional type. Money transactions, eBanking, educational platforms, marketing via internet, trading online - all that activities are examples of e-commerce. 
Types of e-commerce by channels

\begin{tabular}{|c|c|}
\hline Types & Characteristics \\
\hline B2B & $\begin{array}{c}\text { E-commerce that include all types of electronic transactions of products or } \\
\text { services. According to type his transactions have to be between different companies } \\
\text { or enterprises. }\end{array}$ \\
\hline B2C & $\begin{array}{c}\text { Business to customer its direct commercial relationship in online form. That is } \\
\text { the most popular and most dynamic type of e-commerce. Because of development of } \\
\text { internet technology and emergence of tremendous amount of websites B2C has } \\
\text { increased as well. Today it is much easier to find products on web and buy. }\end{array}$ \\
\hline C2C & $\begin{array}{l}\text { Customer to customer is a type of e-commerce when transaction is done between } \\
\text { two people with the help of third part. This third part is a web platform that allows to } \\
\text { fined needed people and their goods. Example of such platform is eBay or OLX }\end{array}$ \\
\hline C2B & $\begin{array}{c}\text { Customer to clients it's the type of e-commerce were customer is someone who } \\
\text { makes product or service for company which help the enterprise to end business - } \\
\text { process. For example, on website where freelancers could make their job for } \\
\text { company's clients. In this case freelancers are "C" and website "B". }\end{array}$ \\
\hline B2G & $\begin{array}{c}\text { Business also can make e-commerce transactions to government. Government } \\
\text { needs different services that are done via internet. }\end{array}$ \\
\hline C2G & $\begin{array}{c}\text { Customer to government it's a type of e-commerce when transaction requires } \\
\text { interaction between authority and citizens. For example, app "Dia" in Ukraine that } \\
\text { people to get services from the government or people can pay taxes or penalties. }\end{array}$ \\
\hline
\end{tabular}

One of the most accurate example of successful e-commerce business is Amazon Inc. According to FXSSI, "On January 7, 2019, Amazon became the most expensive company in the world for the first time overtaking its competitor - Microsoft [9]. Today, it ranks fourth in the list of the most valuable companies". Amazon started as a small retailor of books, hardware, software and CD's. However, today it is one of the most successful company in the world that created huge marketplace. According to MARKINBLOG in 2021 Amazon is the biggest e-commerce company by revenue.

JD.com, Alibaba, Suning.com and Meituan-Dianping has 2,3,4 and 5 place accordingly and all of them are Chinas. [12] As a result they have great connection with customers all around the world and boosts economy of China.

Good example is Alibaba Group that was rapidly growing since its foundation in 1999. For many people in Ukraine and others Eastern European countries more familiar sounds Aliexpress. It is the biggest virtual trading platform in China. It also has big impact on Ukrainian market. Many retailers are buying products using this platform and sell with high value edit.

The other well-known e-commerce company is eBay Inc. that was founded in 1995. EBay Inc. is a global commerce platform that enables buyers and sellers around the world to trade. Project took a year to become a million dollar business. Their portfolio of brands includes eBay Marketplace and eBay Classifieds Group, operating in 190 markets around the world. [25]

In USA online spending represented $21.3 \%$ of total retail sales for the year, according to Digital Commerce 360 estimates. Amazon accounted for nearly a third of all ecommerce in the United States.[5] In 2020 online trade has raised on $44 \%$ in a year and $\$ 861.12$ billion Americans have spent online. Such triple jump was the highest annual growth of e-commerce in USA. According to Eurostat, in $202072 \%$ of EU citizens that have internet were shopping online. According to Statista in the same year, over two billion people purchased goods or services online, and during the same year, e-retail sales surpassed 4.2 trillion U.S. dollars worldwide.

One of the most well-known e-commerce company in Ukraine is ROZETKA.UA LLC. This online marketplace which is the best example of e-commerce in Ukraine. Some people say that it's Ukrainian Amazon. It works nearly the same way. On this platform you can find not only goods of ROZETKA.UA but also goods from other retailers and producers. Frankly speaking it is hard to compete with this corporation. Web-site was opened in 2005, in 2016 it gained Ukrainian language version, in 2018 the company owners stated about 2.5 million of goods available on platform [29]. The other well-known e-commerce company is EVO that holds Ukrainian web-site Prom.ua. The website was founded in 2008 at the same time as the other similar web-site for different countries for the same purpose and by the same company. In 2018 on Prom.ua was sold goods in equivalent of 10.5 billion hryvnas. At the same time commodity turnover has risen on $47 \%$ and average purchase price on 5\% according to ain.ua [1]. Also EVO owns Shafa.ua that was founded in 2013. This web-site specializes on commodity that was already used. However, in Ukraine exist much more well-known e-commerce company that specializes on commodity that was used than Shafa.ua. OLX used to be called Slando till 2014. Slando Ltd firstly was opened in London by Michael Pennington and Simon Crookall together with eBay. In 2007 the company emerged on Ukrainian market and was bought by Naspers group in 2011 [28;19;30]. Today OLX.ua its large online platform in Ukraine. In 2020 money turnover of the service was more than 12 billion hryvnas [7]. On that platforms except Prom.ua people and enterprises can sale and bay not only goods but also services. That platforms can help businesses in Ukraine to get to the e-commerce faster or at list to try it out.

Today even Ukrainian government start using some of aspects of e-commerce in sphere of public services. Application "Diia" is a good example of that. In resent time Ukrainians are able to use their documents in electronic form. This types of documents are legitimate for transport, such banks as Alliance, Pravex, ProKredo, Industrialbank, Pivdennyi, Akordbank. Diia is also legitimate for Administrative Services Centers and Ministry of Internal Affairs. 
Citizens are able to register as a private entrepreneur, got subsidy for real estate or provide and register building documents using the application. There you can also automatically receive COVID - certificates of vaccination that will be legitimate even abroad. On web-site of "Diia" there are available free educational courses in online form about public services. That courses are available for ordinary citizens as well as for public servants. On September 28,2021 application "Diia" used 7 million users. Because of importance of data such as personal documents there is a high risk of hacker attack. That is why informational security of the application is on the high level. While restarting user gets his electronic sign in form of confirmation of face scan. Developers of "Diia" announced about $35000 \$$ of reward for once that are would be able to hack the application. Today the Ministry of electronic transformation and digitalization continues to develop the application and be innovative [23].

Due to pandemic of COVID-19 there was predicted economy crisis that could harm household much harder than even crisis in 2008. Despite the fact, that world economy has slowed down and stock markets have fall down as well as prices on oil, e-commerce became important for businesses and economies. Enterprises that was able to go digital have survived.

Rapid changes of business environment and realities of lockdowns required rapid adaptation. Actually the biggest economies were already going to digitalization of business even before COVID - 19. However, pandemic speed up this process. Despite the experience and efforts of some governments to accelerate e-commerce during the COVID19 crisis, persistent digital divides imply that not everyone has been able to participate. [16] So the key task for Ukrainian government is to make effective regulations that will help businesses to survive lockdowns. The key tasks for businesses are to change business model or even economy spheres in a way that will prevent bankruptcy.

There are a lot of regulations needed to minimize economy crisis. According to The Conversation [24], there are 4 ways to rescue economy:

In 2021 it is import to encourage economic growth at the first place. Governments have to understand that current situation might require raising taxes or cutting spending quickly to stabilize the debt-to-GDP level. In this case there will be necessity to make fiscal correction to stabilize public finances, but it will be needed less corrections if economy recovery is fast.

There is necessity to build confidence. Governments have to create clear strategy to restore economic confidence. Because without economic confidence people and businesses will be unsure in future and that will cause slowing down of the economy. There need to create such strategy to be prepared to the future waves.

Linked to this need to reduce uncertainty, there is no trade-off between health and the economy. The condition of health system and the level of spreading the infection interferes the economy. That is why countries that have done better at the level of spreading the infection have also done better reducing the economic slump.

- If there is a clear economy strengthening than governments as the policymakers should stimulate aggregate demand in the economy. It means that there will be need to cut taxes and support sectors or parts of the workforce that was effected .

If there is a strengthening of economy government should take steps to cut taxes and support particular sectors and parts of the workforce that was effected by pandemic COVID-19 the most. It is necessary to help sectors like tourism, cinemas and etc [24].

However, many countries have different factors that interfere on economy and different sector of economy that have the biggest influence on GDP. In Ukraine government should try do boost spheres of production goods with high value edit. As long as world market might change because of rise of potential policies of protectionism among countries Ukraine needs to rise purchasing power of citizens. While pandemic of COVID-19 there are needed two factors existing together: customers with high purchasing power and e-commerce companies.

How to make it works? Ukraine has a big potential of making all transactions, production and other ways of forming GDP in online format. E-commerce would not depend from pandemic if manufacturing will be more automatized. Purchasing power could be boosted by implementing labor in e-commerce as much as possible. Research done by Jorda O., Singh S. and Taylor A. [10] has shown that changing business model to e-commerce will minimize not only current consciences of pandemic but also will be successful decision in a long run. E-commerce can solve four issuing situations:

1. Retailers can identify and enforce controlled actions. They need to identify, optimize and re-access existing technologies and business models. In particular, they need to understand how their competitors work and interact with customers to reduce response time and optimize communication channels.

2. All retailers, but especially grocery stores, are reviewing their business continuity plans to reassure customers that their needs will be met and to cope with the inevitable constraints caused by rapid change of demand.

3. Businesses need to understand their financial needs as well as the important role they play in the marketplace. An open and detailed online supermarket will assure customers that their needs will be met.

4. Messages that retailers spread online during emergencies, should contain information about the availability of products on the shelves and in digital outlets; control panic purchases by limiting the amount that consumers can buy; develop and implement consumer protection plans and employees; to promote the general health of the population; and use surveillance measures to limit the spread of the virus. [20]

The most vulnerable to lock-downs were small and medium-size business. According to Ministry of economy of Ukraine GVA (Gross value added) of the country in 2020 consisted of $26.6 \%$ value created by small enterprises and $39.8 \%$ by medium-size enterprises. [14] That is why pandemic crisis could have dramatic influence on economy. According to reports of MEU that was already mentioned the worst interference has experienced the service sector. Food service sector has decrease on $28.5 \%$ by amount and sector of transportation services on $16.4 \%$. 
Significantly less losses had industries that are focused on the domestic market and those that were able to quickly adapt their activities to new conditions, using digital technologies in a distance. Examples are the pharmaceutical and chemical industries, the IT sector, the financial sector and, healthcare. Also successfully increase amounts of production managed such sectors as construction $(+5.2 \%)$, wholesale and retail trade $(+4.9 \%)$, information and communication $(+2.3 \%)[14]$.

Index of business confidence in sphere of providing services

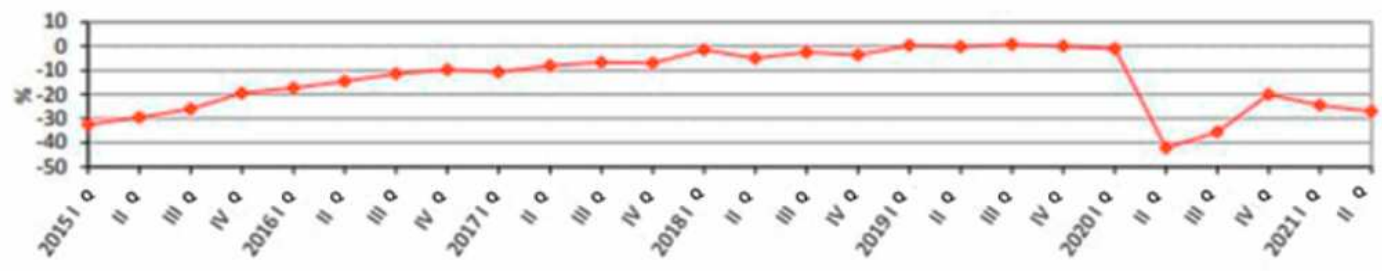

All of components of estimation of this index has such seasonally corrected values of balances:

* about business situation in January - March of 2021 - minus 31\%

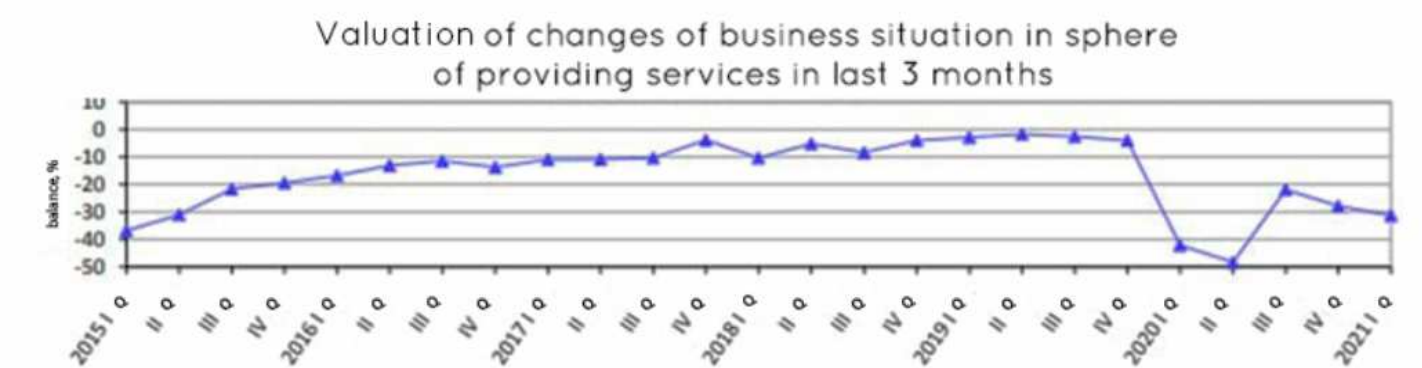

* valuation of demand on services (amount of realization of services) in January -

March of 2021 - minus $30 \%$ while in second quarter of 2021 expected index was minus $19 \%$

\section{Pic. 1. Expected development of business activity in sphere of services in 2021 in Ukraine [15]}

In Pic.1. we can see expectation of business development prospects in sphere of services in second quarter of 2021. First diagram is showing business confidence index. Second diagram is showing how business situation has changed in sphere of services.

To make changes and defined main issues enterprises have to analyze 4P's of marketing. Changing them would change business model. The main emphasize is on ability to learn quickly and be incredibly flexible. To visualize this process let's compare strategies of such spheres as restaurant business, beauty salon, cinemas, theaters, sphere of transportation, tourists sector. Example of new business model is built on experiences of existing enterprises in different countries $[3,4,6]$.

Table 2

Business model transformed into e-commerce for Restaurant business

\begin{tabular}{|c|c|c|}
\hline \multirow[t]{2}{*}{ 4P's } & \multicolumn{2}{|c|}{ Restaurant business } \\
\hline & Current business model & New business model \\
\hline Place & $\begin{array}{l}\text { Physical place of selling in restaurant or café. } \\
\text { Customer consume products mostly in lobby } \\
\text { and less frequently takes option "to go". } \\
\text { Creative interior }\end{array}$ & $\begin{array}{l}\text { Replace lobby consumption on "to go". } \\
\text { Implementing delivery option. Orders are } \\
\text { done via own website or other marketplace } \\
\text { platform online. User experience and user } \\
\text { interface on high level. }\end{array}$ \\
\hline Price & $\begin{array}{c}\text { Setting price according to target audience and } \\
\text { positioning }\end{array}$ & Lowering prices as much as possible \\
\hline Promotion & $\begin{array}{c}\text { Make live events, master classes, discounts, ads } \\
\text { in social media, ads in Google Ads, fliers on } \\
\text { streets. Some of such }\end{array}$ & $\begin{array}{c}\text { Make online master classes, ads in google, } \\
\text { social media, search engine optimization } \\
\text { (SEO), search engine marketing (SEM), } \\
\text { promoting programs of support of local } \\
\text { enterprises. }\end{array}$ \\
\hline Product & $\begin{array}{l}\text { Less developed, not all products are properly } \\
\text { adjusted to delivery mode. }\end{array}$ & $\begin{array}{l}\text { Highly developed, all products can be } \\
\text { delivered, selling certificates. }\end{array}$ \\
\hline
\end{tabular}

Product is less developed because the enterprise has to compete mostly with local cafeterias or restaurants. When enterprise comes to digital marketing and e-commerce it immediately gets competitors around whole city or town. While lock-downs one of the most important factors are social media, search engine optimization and search engine marketing of web-sites. For restaurants and coffees in big cities with developed infrastructure of delivery it is 
important to have own web- site. For restaurant business in small towns having accounts in social medias could be enough. It is important to be flexible, have ability to predict demand, income and casts under such conditions. Investing in communication with customer via social media or web-site has long-term effect on business. However, entrepreneurs must understand how much potential they have and for how long they will be able to be unprofitable. For some businesses it is reasonable to close for some uncertain period.

Table 3

Business model transformed into e-commerce for beauty salons

\begin{tabular}{|c|c|c|}
\hline \multirow[t]{2}{*}{ 4P's } & \multicolumn{2}{|c|}{ Beauty salon } \\
\hline & Current business model & New business model \\
\hline Place & Physical place of providing services. & $\begin{array}{l}\text { Physical place of providing services that } \\
\text { requires direct contact with the client and e- } \\
\text { commerce for additional services. Providing } \\
\text { services "with delivery" of workers on places } \\
\text { of clients. }\end{array}$ \\
\hline Price & Prices that include only traditional costs & $\begin{array}{l}\text { Prices that include also cost for additional } \\
\text { protecting equipment for workers, testing, } \\
\text { transportation and costs for using e - } \\
\text { commerce ( Web-sites, services online) }\end{array}$ \\
\hline Promotion & $\begin{array}{l}\text { Promotion in social media, physical banners, } \\
\text { discounts }\end{array}$ & $\begin{array}{c}\text { Promotion in social media, physical banners, } \\
\text { discounts, promotion via own channel on } \\
\text { YouTube }\end{array}$ \\
\hline Product & $\begin{array}{l}\text { All services are provided in salon. Also there } \\
\text { are a lot of people in building. It causes a high } \\
\text { risk of being infected. }\end{array}$ & $\begin{array}{c}\text { Services are provided in salon with singe } \\
\text { client. Additional services (appointments, } \\
\text { information, promo codes, selling certificates, } \\
\text { delivering services on place of client. Highest } \\
\text { level of safety for workers and clients. } \\
\text { Frequent disinfection of tools, level of PPE of } \\
\text { employees - B [19] }\end{array}$ \\
\hline
\end{tabular}

There are into four categories of personal protective equipment (PPE) that are based on the degree of protection afforded.

Level B - protection is needed for situations when respiratory protection has to be on the highest level. However, such level B doesn't protect skin and eyes at the high level. A typical Level B ensemble includes:

- $\quad$ Positive-pressure (pressure-demand), self-contained breathing apparatus (NIOSH approved), or positive-pressure supplied air respirator with escape SCBA.

- Chemical resistant clothing (overalls and long-sleeved jacket, coveralls, hooded two-piece chemical splash suit, disposable chemical resistant coveralls.)

- Gloves, outer, chemical resistant.

- Gloves, inner, chemical resistant.

- $\quad$ Boots, outer, chemical resistant, steel toe and shank [27].

As long as transformation of business model that was mention in table 3 requires big amount of investments and will interfere the price such transformation could be appropriate for salons that are positioning themselves as premium. For middle class salons such business model could be implemented, however they should cut some options as for example delivery and building own web-site. They can still work in e-commerce using different platforms or accounts in Facebook and Instagram.

However, work of many salons also depends from restrictions of governments. In many countries beauty salons are required to stop working. That is why they should make association or use existing one to communicate with government about allowing work with high protection level. Also such association can be created with the aim to finance and promote platform created for transforming some beauty services to e-commerce. 
Business model transformed into e-commerce for cinemas

\begin{tabular}{|c|c|c|}
\hline \multirow{2}{*}{ 4P's } & \multicolumn{2}{|c|}{ Cinemas } \\
\cline { 2 - 3 } & Current business model & New business model \\
\hline Place & In building. Cinema hall is fully exploited & $\begin{array}{c}\text { In building in case if hall is used on half. Via } \\
\text { online platform if in country work of cinemas } \\
\text { is prohibited. }\end{array}$ \\
\hline Price & $\begin{array}{c}\text { Price for tickets are set according to format } \\
(2 \mathrm{D}, 3 \mathrm{D}, 4 \mathrm{D}) \text { and cots. High prices for snacks } \\
\text { and beverages. }\end{array}$ & $\begin{array}{c}\text { Making discounts, lowering prices on online } \\
\text { platforms, selling certificates, creating account } \\
\text { on Patreon to rise donations from local } \\
\text { community. }\end{array}$ \\
\hline Promotion & Adds before performances, adds in social \\
media, on banners. & $\begin{array}{c}\text { Promotion of Patreon account, promotion of } \\
\text { online platforms. Promotion via own channel } \\
\text { on YouTube in videos about movies. }\end{array}$ \\
\hline Product & $\begin{array}{c}\text { Services that include showing movies, selling } \\
\text { snacks and beverages. }\end{array}$ & $\begin{array}{c}\text { Services are provided with high level of } \\
\text { protection. Online platform has high user } \\
\text { interface and experience (UI/UX) design. }\end{array}$ \\
\hline
\end{tabular}

Transforming business of cinemas into e-commerce is the reasonable decision in case if according to government restrictions it is prohibited to open traditional cinemas. However, e-commerce cinemas will face with some issues. Firstly, on market of streaming services are a lot of strong competitors like Netflix, HBO Max, Disney + etc. That's why UI/UX design on web-site should be on as high level as possible. Also that competitors have large and very different audience, so Ukrainian online cinemas have to translate not only movies from abroad but also specialize more on Ukrainian cinematography. As long as cinema is online and isn't able to sale snacks and beverages any more, it could sale online boxes with sets for "home watching".

Business model transformed into e-commerce for theatres

\begin{tabular}{|c|c|c|}
\hline \multirow{2}{*}{ 4P's } & Current business model & Theaters \\
\cline { 2 - 3 } & Physical theatres & $\begin{array}{c}\text { Online translations on platforms like Patreon } \\
\text { or on streaming services created by } \\
\text { associations of theatres around the country. }\end{array}$ \\
\hline Price & Prices include rent and utilities & Prices should be lowered \\
\hline Promotion & Poor promotion & Promotion in social media \\
\hline Product & $\begin{array}{c}\text { Performance that is shown to audience in real } \\
\text { time in theatre }\end{array}$ & $\begin{array}{c}\text { Performance that is shown to audience in real } \\
\text { time in online format on platform of or not in } \\
\text { real time on Patreon. }\end{array}$ \\
\hline
\end{tabular}

For many theatres might be good opportunity to try Digital players and platforms like Globe player, Digital theatre, Marquee TV or other platforms [26]. In many countries it is not allowed to open theatres, in other countries theatres decides not to open by themselves because of low profitableness of half full theatre. Actually today such business is in very dangerous situation. Most of theatres are small and have no extra capital for promotion or paying rent without working for a long time. Today theatres have to appeal to authorities about support as long as they have value for society not only as business but also in sphere of culture.

One of the most important factors of online purchasing it is safety. It means that your site or account on social media has to be trustful for customers. It also means that you must be prepared against cybercrime. So the aim is to ensure your customer that your business is trustworthy and try to prevent cybercrime. Cybercriminals can act indifferent ways. For instance, customer - deceiver can easily let businesses to pay for their purchase. Is critical for e-commerce companies to take measures for financial protection. Another important thing is safety of customer's data. If someone can steel them then it will cause a lot of troubles for the company. It will lose trust. The same think might happen if someone pretend to be your employee or if there is duplicate of your web-site or social media account.

\section{Conclusions from this research and prospects for further exploration in this direction.}

E-commerce has much broader definition then it might seem in the first place. It is a business model that can be used in different ways. Using such model or even some aspects of it could be very helpful to businesses especially while period when close contact with other people is dangerous. Today under condition of pandemic and lock downs ecommerce has become very actual. Even such types of businesses as restaurants, café, beauty salons, cinemas and theatres can partially transform their business into e-commerce. There are a lot of successful examples such as Amazon, eBay, Alibaba. In Ukraine the most well-known e-commerce companies as ROZETKA, Prom.ua, OLX.ua are a good examples of success. However, entrepreneurs must have support from government. The government has to prepare legislative environment according to strategy of recovery of the economy. A lot of Ukrainians are employed in IT sphere or are freelancers and are used to work online. Even government of Ukraine has developed application "Diia" to make sphere of providing public services online. Ukrainian companies have great potential in e-commerce using a lot of channels. That is why e-commerce is a grate tool to save businesses and recover economy. 
Further research will be to study other force majeure factors that may affect the development of e-commerce.

\section{References.}

1. AIN, Ukrainian online magazine on IT business (2018), "E-commerce in Ukraine has grown to UAH 65 billion", available at: https://ain.ua/2018/12/17/elektronnaya-kommerciya-v-ukraine-dorosla-do-65-mlrd-grnocenka-kompanii-evo/ (Accessed 10 October 2021).

2. BBC news, Ukraine (2020), "Coronavirus in numbers: how the world's economy has changed", available at: https://www.bbc.com/ukrainian/features-51994936 (Accessed 1 October 2021).

3. CDC Centers for Disease Control and Prevention (2020), "COVID-19 Employer Information for Beauty Salons and Barbershops", available at: https://www.cdc.gov/coronavirus/2019ncov/community/organizations/beauty-salon-barber-employers.html (Accessed 10 November 2021).

4. CICAE (2020), "Recommendations for cinemas", available at: http://cicae.org/en/coronavirus/recommendations-for-cinemas (Accessed 10 November 2021).

5. Digital Commerce 360 (2021), "US ecommerce grows 32.4\% in 2020", available at: https://www.digitalcommerce360.com/article/us-ecommerce-sales/ (Accessed 29 October 2021).

6. DW Made for minds (2020), "Survive a pandemic: a recipe from French chefs", available at: https://p.dw.com/p/3nNZZ (Accessed 5 November 2021).

7. Ekonomichna pravda (2021), "OLX Ukraine: how it earns more than a billion a year, three "immortal" fraud schemes and how delivery will change", available at: https://www.epravda.com.ua/publications/2021/06/15/675004/ (Accessed 1 October 2021).

8. Eurostat statistics explained (2021), "E-commerce statistics for individuals", available at: https://ec.europa.eu/eurostat/statistics-explained/index.php?title=E-commerce_statistics_for_individuals (Accessed 19 October 2021).

9. FXSSI (2021), "Most valuable companies in the world", available at: https://fxssi.com/top-10-mostvaluable-companies-in-the-world (Accessed 21 October 2021).

10. Jorda, O. Singh, S. and Taylor, A. (2020), "Longer-run economic consequences of pandemics", National Federal RReserve Bank of San Francisco working paper series, [Online], available at: https://www.frbsf.org/economic-research/files/wp2020-09.pdf (Accessed 8 October 2021).

11. Kapranova, L.H and Kapranov, M.A. (2016), "Development and current state of e-commerce in Ukraine", Bulletin of Priazovsky Technical University, [Online], available at: http://eir.pstu.edu/handle/123456789/12689 (Accessed 10 October 2021).

12. MARKINBLOG (2021), "List of Largest eCommerce Companies in the World in 2021 (Ranked by Revenue)", available at: https://www.markinblog.com/largest-ecommerce-companies/ (Accessed 2 November 2021).

13. Ministry of Economy of Ukraine (2020), "Report on the activities of the Ministry of Economy of Ukraine in 2020”, available at: https://www.me.gov.ua/Documents/Download?id=96f80724-3343-42f0-8d748164ddc74c66 (Accessed 5 November 2021).

14. Ministry of Finance of Ukraine (2021), "The updated GDP data for 2020 from the State Statistics Service turned out to be better than the forecast", available at: https://www.me.gov.ua/News/Detail?lang=ukUA\&id=d8706334-de39-4346-8947-21dd93615a16\&title=UtochneniDaniVvpZa2020-

RikVidDerzhstatuViiavilisKraschimiNizhPrognoz\&isSpecial=true (Accessed 7 November 2021).

15. State Statistics Service of Ukraine (2021), "Expectations of enterprises in the service sector in the second quarter of 2021on the prospects for the development of their business activity", available at: http://www.ukrstat.gov.ua/operativ/operativ2021/fin/rp/posl/posl_IIkv_2021_u.pdf (Accessed 25 October 2021).

16. OECD (2020), "E-commerce in the time of COVID-19", available at: https://www.oecd.org/coronavirus/policy-responses/e-commerce-in-the-time-of-COVID-19-3a2b78e8/ (Accessed 3 November 2021).

17. Yatsenko, O.M. Hriazina, A.S. and Shevchyk, O.O. (2019), "E-commerce as an element of the global trade system", Actual problems of economics, [Online], available at: https://eco-science.net/issue/n218-2019/ (Accessed 14 October 2021).

18. OMDESIGN (2021), "Movie memorabilia and collectibles e-commerce website" available at: https://www.omdesign.co.uk/our-work/cinema-store-e-commerce/ (Accessed 24 September 2021).

19. Capital (2014), "The Slando brand fell victim to globalization" available at: https://www.capital.ua/ru/publication/28890-vynuzhdennoe-proschanie-brend-slando-stal-zhertvoy-globalizatsiiplokho-izvestnogo-v-ukraine-nazvaniya-olx (Accessed 1 October 2021).

20. Panfilova, D.A (2020), "Digitalization of business in the pandemic conditions: flourishing of ecomerce", Digital Transformations of Ukraine 2020: Challenges and Realities, vol.1., [Online], available at: https://ndipzir.org.ua/wp-content/uploads/2020/12/Tezy_18_09_2020_23.pdf (Accessed 21 September 2021).

21. Prom (2021), "Prom.ua is the largest marketplace in Ukraine", available at: https://prom.ua/ua/about_us (Accessed 10 November 2021).

22. Statista (2021), "E-commerce worldwide - statistics \& facts", available at: https://www.statista.com/topics/871/online-shopping/\#dossierSummary (Accessed 4 November 2021).

23. Diia (2021), “Government services online", available at: https://diia.gov.ua/ (Accessed 10 November

2021). 
24. The Conversation, an independent source of news (2020), "Four ways to rescue the economy from the pandemic", available at: https://theconversation.com/four-ways-to-rescue-the-economy-from-the-pandemic-148690 (Accessed 10 September 2021).

25. The Street (2021), "History of eBay: Facts and Timeline", available at: https://www.thestreet.com/markets/history-of-ebay (Accessed 5 November 2021)

26. TimeOut (2021), "The best theatre shows to stream online right now", available at: https://www.timeout.com/london/theatre/the-best-theatre-shows-to-stream-online-right-now (Accessed 10 October 2021).

27. CHEMM, U.S. Department of Health \& Human Services (2021), "Personal Protective Equipment (PPE)", available at: https://chemm.hhs.gov/ppe.htm (Accessed 1 November 2021).

28. Wikipedia (2021), “OLX”, available at: https://uk.wikipedia.org/wiki/OLX (Accessed 10 October 2021).

29. Wikipedia (2021), "Rozetka.ua", available at: https://uk.wikipedia.org/wiki/Rozetka.ua (Accessed 9 October 2021).

30. Wikipedia (2021), "Slando", available at: https://ru.wikipedia.org/wiki/Slando (Accessed 9 October 2021).

31. You control (2021), "LIMITED LIABILITY COMPANY ROZETKA. UA)", available at: https://youcontrol.com.ua/catalog/company_details/37193071/ (Accessed 7 November 2021).

32. Yudin, O.M Makarova, M.V. and Lavreniuk, R.M. (2011) "E-commerce systems: creation, promotion and development", RVV PUET.

\section{Література.}

1. ुектронная коммерция в Украине доросла до 65 млрд грн: оценка компании EVO. AIN: вебсайт. URL: https://ain.ua/2018/12/17/elektronnaya-kommerciya-v-ukraine-dorosla-do-65-mlrd-grn-ocenka-kompaniievo/ (дата звернення: 10.10.2021).

2. Коронавірус в цифрах: як змінилася світова економіка. BBC news: веб-сайт. URL: https://www.bbc.com/ukrainian/features-51994936 (дата звернення: 01.10.2021).

3. COVID-19 Employer Information for Beauty Salons and Barbershops. CDC Centers for Disease Control and Prevention: веб-сайт. URL: https://www.cdc.gov/coronavirus/2019ncov/community/organizations/beauty-salon-barber-employers.html (дата звернення: 10.11.2021).
4.
Recommendations
for cinemas.
CICAE:
веб-сайт.
URL:

http://cicae.org/en/coronavirus/recommendations-for-cinemas (дата звернення: 10.11.2021).

5. US ecommerce grows $32.4 \%$ in 2020. Digital Commerce 360: веб-сайт. URL: https://www.digitalcommerce360.com/article/us-ecommerce-sales/ (дата звернення: 29.10.2021).

6. Вижити в умовах пандемії: рецепт шеф-кухарів Франції. DW Made for minds: веб-сайт. URL: https://p.dw.com/p/3nNZZ (дата звернення: 05.11.2021).

7. OLX Україна: як заробляє понад мільярд на рік, три "безсмертні" схеми шахрайств та як зміниться доставка. пкономічна правда: веб-сайт. URL: https://www.epravda.com.ua/publications/2021/06/15/675004/ (дата звернення: 01.10.2021).

8. E-commerce statistics for individuals. Eurostat statistics explained: веб-сайт. URL: https://ec.europa.eu/eurostat/statistics-explained/index.php?title=E-commerce_statistics_for_individuals (дата звернення: 19.10.2021).

9. Most valuable companies in the world. FXSSI: веб-сайт. URL: https://fxssi.com/top-10-mostvaluable-companies-in-the-world (дата звернення: 21.10.2021).

10. Jorda O., Singh S., Taylor A. Longer-run economic consequences of pandemics. National Federal RReserve Bank of San Francisco working paper series. 2020. URL: https://www.frbsf.org/economicresearch/files/wp2020-09.pdf (дата звернення: 08.10.2021).

11. Капранова Л.Г., Капранов М.А. Розвиток та сучасний стан е-комерції в Україні. Вісник Приазовського державного технічного університету. Маріуполь. $2016 . \quad № 32 . \quad$ URL: http://eir.pstu.edu/handle/123456789/12689 (дата звернення: 10.10.2021).

12. List of Largest eCommerce Companies in the World in 2021 (Ranked by Revenue). MARKINBLOG: веб-сайт. URL: https://www.markinblog.com/largest-ecommerce-companies/ (дата звернення: 02.11.2021).

13. Звіт про діяльність міністерства економіки України за 2020 рік. Міністерство економіки України: веб-сайт. URL: https://www.me.gov.ua/Documents/Download?id=96f80724-3343-42f0-8d74-8164ddc74c66 (дата звернення: 05.11.2021).

14. Уточнені дані ВВП за 2020 рік від Держстату виявились кращими ніж прогноз. Міністерство фінансів Украйни: веб-сайт. URL: https://www.me.gov.ua/News/Detail?lang=uk-UA\&id=d8706334-de39-43468947-21dd93615a16\&title=UtochneniDaniVvpZa2020-

RikVidDerzhstatuViiavilisKraschimiNizhPrognoz\&isSpecial=true (дата звернення: 07.11.2021).

15. Очікування підприємств сфери послуг у II кварталі 2021 року щодо перспектив розвитку їх ділової активності. Державна служба статистики Украӥни: веб-сайт. URL: http://www.ukrstat.gov.ua/operativ/operativ2021/fin/rp/posl/posl_IIkv_2021_u.pdf (дата звернення: 25.10.2021).

16. E-commerce in the time of COVID-19. OECD: веб-сайт. URL: https://www.oecd.org/coronavirus/policy-responses/e-commerce-in-the-time-of-COVID-19-3a2b78e8/ (дата звернення: 03.11.2021). 
17. Яценко О.М., Грязіна А.С., Шевчик О.О. Електронна комерція як елемент глобальної торговельної системи. Актуальні проблеми економіки. 2019. №8. URL: https://eco-science.net/issue/n218-2019/ (дата звернення: 14.10.2021).

18. Movie memorabilia and collectibles e-commerce website. OMDESIGN: веб-сайт. URL: https://www.omdesign.co.uk/our-work/cinema-store-e-commerce/ (дата звернення: 24.09.2021).

19. Бренд Slando стал жертвой глобализации. Capital: веб-сайт. URL: https://www.capital.ua/ru/publication/28890-vynuzhdennoe-proschanie-brend-slando-stal-zhertvoy-globalizatsiiplokho-izvestnogo-v-ukraine-nazvaniya-olx (дата звернення: 01.10.2021).

20. Панфілова Д.А. Цифровізація бізнесу в умовах пандемії: розквіт е-commerce. Цифрові трансформації України 2020: виклики та реалї, URL: https://ndipzir.org.ua/wpcontent/uploads/2020/12/Tezy_18_09_2020_23.pdf (дата звернення: 21.09.2021).

21. Prom.ua - найбільший маркетплейс України. Prom: веб-сайт. URL: https://prom.ua/ua/about_us (дата звернення: 10.11.2021).

22. E-commerce worldwide - statistics \& facts. Statista: веб-сайт. URL: https://www.statista.com/topics/871/online-shopping/\#dossierSummary (дата звернення: 04.11.2021).

23. Державні послуги онлайн. Дія: веб-сайт. URL: https://diia.gov.ua/ (дата звернення: 10.11.2021).

24. Four ways to rescue the economy from the pandemic. The Conversation, an independent source of news: веб-сайт. URL: https://theconversation.com/four-ways-to-rescue-the-economy-from-the-pandemic-148690 (дата звернення: 10.09.2021).

25. History of eBay: Facts and Timeline. The Street: веб-сайт. URL: https://www.thestreet.com/markets/history-of-ebay (дата звернення: 05.11.2021).

26. The best theatre shows to stream online right now. TimeOut: веб-сайт. URL: https://www.timeout.com/london/theatre/the-best-theatre-shows-to-stream-online-right-now (дата звернення: 10.10.2021).

27. Personal Protective Equipment (PPE). CHEMM, U.S. Department of Health \& Human Services: вебсайт. URL: https://chemm.hhs.gov/ppe.htm (дата звернення: 01.11.2021).

28. OLX. Wikipedia: веб-сайт. URL: https://uk.wikipedia.org/wiki/OLX (дата звернення: 10.10.2021).

29. Rozetka.ua. Wikipedia: веб-сайт. URL: https://uk.wikipedia.org/wiki/Rozetka.ua (дата звернення: 09.10.2021).

30. Slando. Wikipedia: веб-сайт. URL: https://ru.wikipedia.org/wiki/Slando (дата звернення: 09.10.2021).

31. LIMITED LIABILITY COMPANY ROZETKA.UA. You control: веб-сайт. URL: https://youcontrol.com.ua/catalog/company_details/37193071/ (дата звернення: 07.11.2021).

32. Юдін О.М, Макарова М.В., Лавренюк Р.М. Системи електронної комерції: створення, просунення і розвиток: монографія. Полтава: РВВ ПУЕТ, 2011. 201 с.

Стаття надійшла до редакиії 17.11.2021 p. 